\title{
Forma y sentido de un cuento oral. Un tema de encantamiento y peregrinaje
}

\author{
CONSTANTINO CONTRERAS OYARZÚN \\ Y LUIS DE LA BARRA ARROYO \\ Universidad de La Frontera \\ Temuco, Chile
}

1. El CUENTO ORAL EN LA ARAUCANía

1.1. El cuento que se analizará en esta ocasión forma parte de un corpus de narraciones recogidas en sectores rurales de la Araucanía (IX Región de Chile), sectores bastante periféricos con respecto a la ciudad de Temuco, que es la capital regional. Tales narraciones han sido registradas como parte de un proyecto de investigación en el que trabajan los autores de este artículo y que está encaminado a detectar la pervivencia de relatos orales de raíz hispánica en esta área del territorio nacional, tardíamente colonizada y con fuerte presencia de la cultura mapuche ${ }^{1}$. El cuento elegido para esta ocasión es el que se refiere a Un joven encantado en forma de toro y su novia con zapatos de fierro y ha sido seleccionado por lo atractivo de su tema y por la novedad de su estructura narrativa.

1.2. Las dos versiones que se han registrado de este cuento proceden de campesinos hispanohablantes con muy escasa o nula instrucción escolar, los cuales, precisamente por mantenerse alejados de la cultura del texto impreso o de los mensajes audiovisuales que actualmente difunde la televisión, han podido mantener en su memoria varios relatos aprendidos en su infancia y juventud, relatos que ahora han perdido bastante funcionalidad, pero que entonces formaban parte de la comunicación formativa y recreativa que propiciaban los padres y los abuelos, en el ambiente familiar. Los mismos narradores de ahora, que son bastante escasos, pero regularmente de memoria muy fecunda, recuerdan que la narración practicada en el pasado era una actividad muy común, y no

1 El proyecto aludido está en pleno proceso de avance y es patrocinado por la Dirección de Investigación y Desarrollo de la Universidad de La Frontera (proyecto DIDUFRO n. ${ }^{\circ}$ 9804). 
circunstancial como ahora, una actividad extendida y aceptada también en otras ocasiones de la vida social, por ejemplo: durante las largas noches de velorio, o después de las jornadas de trabajo agrícola; recuerdan, además, que era un arte que prestigiaba a quien lo practicaba y que cumplía, en muchos casos, una función ejemplarizadora; en otros casos, una función meramente recreativa, pero no menos importante, pues era una forma de comunicación entretenida que reforzaba los lazos de simpatía entre el narrador y su auditorio y, por extensión, entre los miembros del grupo participante.

\section{PERSPECTIVA DE ANÁLISIS}

2.1. El presente trabajo comprenderá un análisis estructural y comparativo de las versiones de este cuento en sincronía, pero se recurrirá también a aspectos diacrónicos mínimos para fundamentar la persistencia de algunos elementos y la variación de otros en la vida oral de este relato, lo que podrá contribuir también a esclarecer algunas esferas de sentido que surjan del mismo análisis, pues se sabe que las versiones actuales de un mismo cuento popular son siempre una parte pequeña de un texto mucho mayor que ha vivido en la tradición (Pisanty 1995; Camarena 1995; Dannemann 1998). Todo esto refuerza nuestra percepción de que la actividad del narrador popular es también creadora y no meramente repetidora de enunciados.

Hay dos aspectos fundamentales que se pueden formular como hipótesis de trabajo:

1) Este cuento contiene varios elementos que entran en el nivel de lo mágico o sobrenatural; pero estructuralmente se aparta bastante del esquema tradicional del cuento maravilloso, tanto por la trayectoria que siguen las acciones como por la calidad de los personajes o actantes que intervienen.

2) Es difícil aceptar que todos los cuentos de magia o maravillosos tengan una estructura monotípica. Por lo mismo, cada versión particular proporciona también elementos originales, aun cuando exista la voluntad de los narradores de ser fieles al producto textual que ellos alguna vez aprendieron de oídas. Aquí se considera que en un texto que ha vivido por años y siglos en una tradición, son importantes no sólo los elementos que tienden a permanecer estables, sino también aquellos elementos que han variado y que, en algunos casos, llegan a expresar aspectos de la circunstancia inmediata de un narrador o fragmentos de una particular visión de mundo. 


\section{UNIDAD Y VARIACIÓN}

3.1. Se sabe que cada cuento oral se presenta bajo múltiples formas llamadas versiones; y "si se llama la atención sobre las diferentes versiones, con relación a una de ellas o a un arquetipo, se emplea la palabra variante. (Pinon 1965: 24). Con respecto al tema narrativo ya enunciado, se han registrado dos versiones: El torito encantado, versión narrada por don Roque Orellana, de la localidad de Quino (comuna de Victoria), y $E l$ joven que se convertía en toro, narrada por doña Mercedes Caro, de la localidad de Villa Coihueco (comuna de Galvarino). Ambos productos verbales registrados son manifestaciones discursivas o realizaciones particulares de un solo cuento. En este cuento es posible distinguir varias unidades narrativas, las cuales se pueden llamar secuencias (como hacen varios autores, entre ellos Propp), o episodios [unidades narrativas cuya serie constituye la trama de las acciones, según el concepto definido por van Dijk (1992: 155)]. La primera unidad narrativa es la que se refiere a un hecho sobrenatural: un joven vive un encantamiento que consiste en adoptar en la vida diurna la forma de un animal vacuno, cuyo aposento está en una laguna; pero este ser encantado recupera su forma humana por las noches, en el espacio estrecho de su habitación.

3.2. En ambas versiones, se desarrolla a continuación una segunda unidad narrativa, llámese secuencia o episodio, cuyo tema es la búsqueda de una esposa que pueda aceptar la situación tan especial de su pareja. En efecto, el joven pide a su madre que asuma esta acción. Ella recurre a una familia que tiene tres hijas. El joven aniquila a dos de las hermanas, justamente aquéllas que, por miedo, no han podido soportarle su condición de hombre-bestia, y sólo acepta a la tercera, aquélla que, sin temores, le manifiesta su amor.

3.3. Luego se advierte que, en forma cohesionada con esta parte de la trama narrativa, se desarrolla otra secuencia o episodio, cuyo núcleo tiene carácter de motivo, en el sentido de unidad narrativa mínima tipificada por la tradición (Pinon 1965: 12): la transgresión de una prohibición o ruptura del tabú trae una consecuencia inesperada, en este caso, el desencantamiento prematuro, y una sanción: la huida separadora. En efecto, el joven espera que llegue el término de su encantamiento, pero mientras eso no suceda, nadie podrá mirarle el rostro para descubrirle sus verdaderas facciones. Pero es precisamente la mujer elegida como esposa la 
transgresora de esa prohibición: movida por la curiosidad, mientras duerme su amado, en la noche, enciende una luz; él despierta y huye, no sin antes advertir a la mujer que para que ella pague su falta y consiga consolidar su matrimonio, deberá emprender una larga búsqueda hasta gastar siete pares de zapatos de hierro.

3.4. En seguida se desarrolla precisamente la secuencia o episodio del peregrinaje de la mujer hasta gastar los siete pares de zapatos de hierro para reencontrar al joven que debe ser su esposo. La mujer pasa a ser la protagonista de la historia, pues tiene que sortear varios obstáculos antes de conseguir el objeto de su deseo. Y es en este punto donde surgen las mayores diferencias entre una y otra versión. En la primera versión, la heroína (así se la puede llamar) realiza el largo recorrido hasta gastar los siete pares de su singular calzado; pero, además, prueba su identidad y su fidelidad mediante un subterfugio en que intervienen tres prendas valiosas que él le ha regalado. En la segunda versión, la heroína debe hacer también un largo recorrido hasta gastar los siete pares de zapatos de hierro. Se añade un detalle temporal: el recorrido debe durar siete años (segunda alusión al número siete). En esa trayectoria, la mayor dificultad la tiene al atravesar un río caudaloso. Ahí interviene un auxiliar: un águila (o aguilucho) que le facilita el camino a cambio de siete corderos (tercera referencia al número siete) para saciar su hambre. Tales corderos luego resultan ser "lauchones", o sea, simples ratones. Por lo demás, la voracidad del auxiliar es tan grande que la heroína debe entregarle, con mucho dolor, trozos de carne de su propio cuerpo.

\section{OTROS ASPECTOS DE LA VARIACIÓN}

4.1. Hay también una variante de la historia contada que apunta al momento del reencuentro entre ella y él. Según la primera versión, la heroína encuentra al joven casado con otra mujer. Todo su esfuerzo posterior está destinado a anular esa relación y a legitimar su derecho a ser la verdadera esposa, en cumplimiento del compromiso contraído. En efecto, ella conserva tres prendas que él le ha regalado (un espejo, una peineta y una manzana de oro). A ella no le importa emplearse como criada y desprenderse de estos objetos valiosos, con tal de conseguir reunirse con su esposo. Por eso compra con esas prendas la oportunidad de dormir con él durante tres noches; en cambio, la otra mujer hace todo lo posible por conseguir la propiedad de esas prendas, aun a riesgo de quebrantar su matrimonio. Por lo tanto, es la heroína la que pone en evi- 
dencia su fidelidad y no la otra mujer. Por ello mismo, le son restituidas sus prendas $\mathrm{y}$, por supuesto, logra consolidar su matrimonio. Según la segunda versión, la heroína se presenta ante el joven cuando éste está iniciando la celebración de su boda con otra mujer. La boda no se ha consumado y es justo el momento en que la verdadera prometida se identifica y reclama el cumplimiento del compromiso. En esta parte final del relato, esta versión converge con la primera, ya que la historia culmina también con la consolidación del matrimonio.

4.2. Otras variantes son aparentemente secundarias, pero alguna importancia tienen para el sentido global del cuento. Ambas versiones hacen referencia a una fuente luminosa como el factor que sirve para revelar la identidad del ser encantado; pero surgen diferencias. Según la primera versión, es el tiempo que dura la llama de un fósforo lo que provoca el despertar del joven durmiente; según la otra versión, es el contacto con un trozo de cera caliente de la vela (un "cerote") lo que provoca tal despertar. Otra variante es la que se refiere al hecho que desencadenó la mutación o metamorfosis del joven en bestia y su consiguiente encantamiento. La primera versión deja entrever simplemente que se habría producido por designio divino; la segunda versión, en cambio, señala explícitamente que este fenómeno fue producto de un castigo divino, por incumplimiento de una promesa por parte de la madre.

\section{ESTRUCtURA DE LAS ACCIONES. LO MARAVILLOSO}

5.1. El cuento en referencia tiene una estructura compleja, ya que las acciones siguen un desarrollo a través de varias unidades narrativas $\mathrm{O}$ secuencias estrechamente relacionadas: $\mathrm{A} \rightarrow \mathrm{B} \rightarrow \mathrm{C} \rightarrow \mathrm{D} \rightarrow \mathrm{E}$. Cada una de estas instancias narrativas corresponde a una particular concreción de las acciones, cuya articulación semántica se puede esquematizar de la siguiente manera:

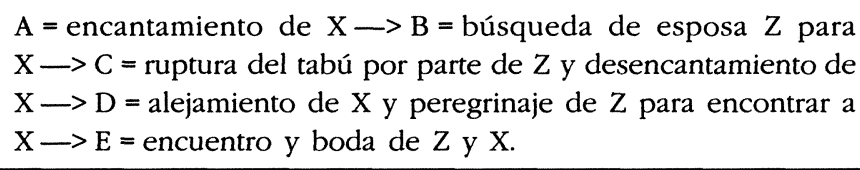

Pensamos que no sería muy acertado aplicar rígidamente a este cuento el modelo de las funciones proppianas formulado para el cuento maravilloso (Propp 1981a: 39-74), porque tanto su estructura narrativa como sus actantes o personajes presentan unas características bastante diferen- 
tes. Aunque sí hay que destacar que lo maravilloso juega un papel importante en el contenido de este relato. Desde luego, tiene ese carácter el hecho de que $\mathrm{X}$ es un personaje que experimenta la metamorfosis por encantamiento: pasa de ser humano a toro y luego de toro a ser humano. Es maravilloso también el hecho de que $\mathrm{X}$ se vuelve paloma para emprender su fuga (segunda versión). Otros elementos maravillosos aparecen en torno al peregrinaje de $Z$ tras el objeto deseado y en circunstancias muy particulares: cuando este personaje se hospeda en casa de la madre del viento Norte y en casa de la madre del viento Sur (primera versión); y cuando el mismo personaje es auxiliado por un aguilucho para atravesar un río caudaloso (segunda versión).

5.2. Lo singular del cuento aquí analizado es su carácter de historia compartida por dos personajes. Toda la primera parte está centrada en la esfera de acción del personaje masculino; en cambio, la segunda parte está centrada en la esfera de acción del personaje femenino y es este personaje el que asume la calidad de protagonista. En efecto, es la mujer, y no el varón, quien emprende la búsqueda del objeto deseado que culmina con la boda, a diferencia del esquema más común de los cuentos maravillosos tradicionales. Y la mujer alcanza la calidad de heroína, pues es ella la que debe sortear los obstáculos y gastar los siete pares de zapatos de hierro en el camino de reencuentro con su prometido. En todo caso, el relato culmina con la última de las 31 funciones señaladas por Propp: la referente al matrimonio del héroe con la princesa y su ascenso al trono (ibid.: 72). Una salvedad: en el caso del relato estudiado, habría que hablar del matrimonio de la heroína con el príncipe buscado. El consiguiente ascenso al trono está sólo insinuado en la primera versión; pero, queda bastante bien explícito en la segunda.

5.3. Hay, además, otra diferencia con respecto al esquema más común de cuento maravilloso. Por lo general, en esta clase de cuentos el héroe vence los obstáculos mediante poderes extraordinarios. En muchos casos éste realiza sus proezas con ayuda de un objeto auxiliar revestido de poderes mágicos, el cual le ha sido entregado por un donante en recompensa por algún favor concedido. En cambio, la heroína del cuento aquí analizado no está revestida de ningún poder sobrenatural. Es cierto que, según la primera versión, ella recibe protección o ayuda pasajera de algunas personas; y lleva consigo tres objetos donados por el joven (un espejo, una peineta y una manzana de oro); pero estos objetos - salvo la manzana de oro- son objetos comunes y ninguno de los tres está dotado de poderes sobrenaturales. Según la segunda versión, la heroína es 
ayudada por un aguilucho para pasar un río caudaloso, a cambio de carne de ratones y bocados de su propio cuerpo, pero no recibe de él ningún objeto mágico. Tampoco después de esas entregas queda dotada de algún poder extraordinario. La larga caminata (hasta gastar los siete pares de zapatos de hierro), impuesta como sanción por ruptura del tabú y también como prueba de fidelidad, es cumplida por la joven sin tener que recurrir más que a su propia fortaleza física.

\section{Más allá de las ACCiONES. Otros SENTIDOS}

6.1. Si bien es cierto, lo determinante en un cuento es la progresión de las acciones y las acciones implican temporalidad, es decir, transcurso de tiempo, los elementos secundarios también son indicadores de sentido. En las versiones analizadas, es posible advertir, por ejemplo, que aunque las acciones se desarrollan en un tiempo pasado pero inespecífico y en un espacio lejano y poco concreto, aparecen alusiones a elementos de la cultura regional de los narradores, que viven en el sur de Chile. De pronto el palacio aparece emplazado en un fundo ('propiedad privada rural de gran extensión perteneciente a un hombre acaudalado'), el príncipe es percibido como un "futre" (denominación que recibe comúnmente aquí, con cierto matiz despectivo, el 'hombre elegante y adinerado'). Aparece también el contraste social patrona / criada, o el contraste patrón / mozo. Además, aparecen alusiones a la función social del compadrazgo o, más específicamente, a la solidaridad entre comadres, rasgo bastante común en algunos sectores de la vida nacional. Hay alusiones a la hospitalidad campesina y al calor de la amistad entre gentes que comparten el mate, la tortilla y el queso mientras conversan. De algún modo, esto pertenece al marco en que transcurren los sucesos. Pero se pueden advertir también algunos enunciados que proyectan una determinada valoración de la materia narrativa desde la perspectiva de la propia circunstancia de los narradores. Esta categoría es la que van Dijk llama precisamente evaluación, la cual no forma parte propiamente de la trama, "sino que se trata de una reacción del narrador frente a la misma" (1992: 155). Unos ejemplos claros: el narrador de la primera versión, al referirse al calor de la amistad campesina, dice: "Antes no fallaba eso". El mismo narrador al referirse al atuendo femenino opina: antes no eran na(d)a vestiditos pu(es); eran vestidazos: llegaban a los tobillos, abajo".

6.2. Más importante, porque afecta el nivel de la trama, es la condición social de los personajes protagonistas. En la primera versión, éstos 
pertenecen a familias de modestos campesinos; pero su condición social cambia a lo largo de su trayectoria de tal modo que por distintas circunstancias llegan a situarse en un ambiente propio de la realeza. Lo cierto es que la consumación de la boda tiene lugar en un espacio palaciego. Esto no resulta muy explícito en la primera versión, pero en la segunda, aunque nada se dice de la condición social de la mujer, del joven se dice que era hijo de reyes, o sea, príncipe. Y queda explícito que la fiesta de la boda se realiza en un espacio real específico: el Palacio de los Siete Garfios. Y queda explícito también que los miembros de la pareja alcanzan la categoría de reyes. De este modo, aunque con ligeras variantes, ambas versiones subrayan la consolidación del matrimonio y el ascenso social como instancias idealizadas de mayor equilibrio y bienestar.

\section{OTRAS VERSIONES CHILENAS; UNA VERSIÓN ESPAÑOLA}

7.1. En el marco del folklore chileno, hay versiones del mismo cuento que han sido registradas en otras regiones del país y en otros tiempos. En la obra Cuentos folklóricos de Chile, de Yolando Pino Saavedra, se presentan cinco versiones de cuentos acerca de un esposo o novio animal, cuya esposa hace cesar el encantamiento (Pino Saavedra 1960: 192214). En la versión 45 , un hombre encantado asume la forma de culebrón; en la 46, un príncipe no permite ser visto de noche; en la 47 , un príncipe asume la forma de venado; en la 44, un rey ordena que la hija de su compadre se case con un torito; pero la versión que más se acerca a las analizadas es la 43, pues en ella se cuenta la historia de un príncipe encantado en forma de toro que se enamora de una joven. A ésta le está vedado ver el rostro de su novio. Pero enciende un fósforo para verlo y a él le cae la pavesa sobre la cara. Roto el encantamiento, ella debe gastar zapatos de hierro en la búsqueda hasta encontrar a su amado. Y lo encuentra en forma de tronco. Limpia el tronco para desencantarlo. Luego la pareja contrae matrimonio.

7.2. Otra versión similar es la que aparece en la obra del mismo autor Cuentos orales chileno-argentinos (Pino Saavedra 1970: 52-63). Lleva el n. 5 y su título es Bodas oscuras. En este caso, el matrimonio se realiza entre una joven y un varón encantado en forma de ogro o monstruo. Igualmente ella, pese a la prohibición, descubre el verdadero rostro de su esposo y luego, como castigo, debe gastar zapatos de hierro en su búsqueda hasta encontrarlo. Finalmente, el mismo autor, en su obra Cuentos folklóricos chilenos de raíces hispánicas (Pino Saavedra 1992: 44-50), 
registra una versión llamada La princesa que gastó siete pares de zapatos de fierro, pero esta versión nada tiene que ver con las acciones del cuento analizado; en cambio, su trama guarda una relación más estrecha con la de Las zapatillas bailarinas, que es un cuento muy distinto.

7.3. Es muy importante la relación intertextual que se puede establecer entre nuestras versiones y la consignada en el Catálogo tipológico del cuento folklórico español, de Camarena y Chevalier (1995: 241-246). La versión peninsular que estos autores presentan fue recogida en la década de los 40 por Aurelio M. Espinosa en el área castellana y lleva por título El lagarto de las siete camisas. Según esta versión, quien casa con una joven es un príncipe encantado que por el día se cubre con siete camisas de lagarto y por las noches se despoja de ellas para recobrar su forma humana. Advierte a su mujer que si esas prendas son tocadas, él no podrá desencantarse; pero la madre del príncipe quema las camisas y él queda aún más encantado y busca refugio en el Castillo de Irás y no Volverás. Para encontrarlo, la esposa deberá gastar siete pares de zapatos de hierro y otros tantos deberá gastar su pequeño hijo. Después de una larga búsqueda, la mujer llega al Castillo, donde ya su esposo se dispone a casar con otra mujer. En su camino recibe la ayuda de una viejecita que resulta ser la Virgen, quien le regala tres nueces mágicas, de las cuales salen una rueca, un huso y un ovillo de oro. La novia procura adquirir estos objetos y la verdadera esposa se los entrega a cambio del privilegio de dormir con el esposo. De esta manera, se reencuentra la pareja y se restablece su matrimonio.

\section{MOTIVOS, TIPO Y FILIACIÓN}

8.1. A partir de la sincronía, este análisis se ha adentrado ya un poco en la diacronía. Tal vez convenga explorar un poco más en este sentido. En las versiones analizadas es posible identificar algunas unidades narrativas menores típicas que tienen la calidad de motivos, tal como han entendido este concepto Aarne y Thompson al configurar su catálogo internacional (Thompson 1972). Son muy claros -entre otros- los siguientes motivos: L54.1, Hija acepta casar con el monstruo; D621.1., Animal de día; hombre de noche; C932, Pérdida del esposo por romper tabú; C916.1, Transgresión revelada por chorrera de la vela; H1385.4, Búsqueda del esposo desaparecido (o H1385.5, Búsqueda del amante desaparecido); Q502.2, Castigo: gastar zapatos de hierro caminando; H1233.1.1, Vieja ayuda en la búsqueda (sólo en la primera versión); B552., Persona transportada 
por un pájaro (sólo en la segunda versión); D1364.7, Brebaje que hace dormir (sólo en la primera versión); N681.1, Mujer encuentra a su esposo perdido justamente cuando va a casar con otra; etc. Estas referencias sirven sólo para verificar que las versiones registradas forman parte de una tradición textual; pero no revelan mucho acerca de la estructura narrativa ni del sentido discursivo.

8.2. Más importante, para entender el desarrollo diacrónico del cuento y su difusión geográfica, es el índice tipológico internacional, establecido también por Aarne-Thompson. Al respecto, es indudable que las versiones analizadas corresponden al cuento-Tipo n. ${ }^{\circ} 425 \mathrm{~A}$ (El monstruo lanimall como esposo) (Thompson 1972: 142). Thompson refiere que se han registrado, especialmente en la parte occidental de Europa, muchísimas versiones de este cuento, algunas de las cuales revelan la influencia del cuento de Cupido y Psique, según el tratamiento que le dio Apuleyo en su obra El asno de oro, en el siglo II después de Cristo (cf. Lida 1976); pero indica también que tal forma clásica del cuento "no representa la forma original de la que las modernas versiones europeas se derivan" (Thompson 1972: 142). Según Thompson, el Tipo 425 A tiene muchas variaciones en su parte inicial, pero en lo nuclear de la trama una muchacha ha sido obligada a casarse con un ser encantado que, por lo general, es hombre de noche y monstruo o animal de día. Ella anhela desencantar a su esposo para tener una vida normal y lo logra mediante un beso o mediante lágrimas, o bien quemando su piel de animal, o algunas veces cortándole la cabeza. "Pero en Cupido y Psique, ella siempre pierde a su esposo sobrenatural porque en alguna forma deja de obedecer instrucciones. Puede suceder que queme su piel animal demasiado pronto, pero más frecuentemente porque conoce y revela el secreto de su insólita forman (Thompson 1972: 142-143).

8.3. "Tan pronto como desobedece - prosigue Thompson-, el esposo la deja, dándole a veces vagas instrucciones sobre dónde poder encontrarlo. Ella comienza de inmediato un largo y doloroso viaje. Algunas veces usa zapatos de hierro que deben gastarse antes de finalizar el viaje" (Thompson 1972: 143). Hasta aquí se puede advertir una correspondencia muy estrecha entre la síntesis que hace Thompson y las versiones orales ahora analizadas. El mismo autor añade que la heroína arecibe objetos mágicos de una vieja (o frecuentemente de tres, una tras otra); pregunta su ruta al viento y a las estrellas; sube una empinada montaña de cristal en cuyo tope encuentra a su esposo. Toda esta parte no aparece, o aparece muy transformada, en las versiones analizadas. Pero vuelve a 
advertirse una correspondencia muy estrecha en la parte final: "Antes de reunirse [con su esposo], ella tiene que obtenerlo de la mujer con quien está a punto de casarse, y en especial hacer que él la reconozca puesto que ha olvidado todo sobre ella. Para lograr esto algunas veces se emplea como doncella y compra con tres joyas el privilegio de dormir con su esposo durante tres noches. El cuento siempre termina con la reunión de la pareja y su feliz matrimonio" (ibidem).

\section{BASE ETNOGRÁFICA. El ASPECTO MORAL}

9.1. Que el tema de las versiones analizadas tenga antecedentes tan antiguos es algo que no deja de llamar la atención. Quiere decir que este relato - como en tantos otros cuentos que han circulado oralmente- descansa en una continuidad de actos de habla, transmisores de contenidos culturales muy antiguos. No es tampoco una curiosidad advertir que cuentos sobre una muchacha que ha sido prometida por sus padres a un animal o monstruo se hayan encontrado no sólo en la tradición cultural de Europa occidental, sino también en antiguos relatos de la Europa del Este. En su libro Las raices históricas del cuento, Propp (1981b) llega a postular que este tema - al menos en lo que se refiere al folklore ruso- estaría relacionado con antiguos ritos de iniciación, en los cuales las hijas eran entregadas a los varones que vivían por un tiempo en casas especiales situadas en el bosque. Tales iniciados - dice Propp- «eran a menudo tenidos por animales, y como tales se enmascaraban" (1981b: 188189). Y agrega que esas casas estaban asociadas también en la creencia popular con el reino de los muertos. "Sabemos ya que, según la creencia - dice- los jóvenes sometidos a la iniciación habitaban temporalmente en el otro mundo" (1981b: 189).

9.2. Pero también es necesario advertir que lo que alguna vez pudo haber tenido fundamento en actitudes y creencias de un determinado grupo humano, al cambiar esa base de sustentación el relato se ha vuelto más ficticio y, por lo tanto, también más abstracto y general. No obstante, es indudable que en las versiones analizadas subyacen algunas ideas de índole moral. Claro está que contienen algunos elementos ejemplarizadores que pueden suscitar reacciones de aceptación o rechazo por parte de la audiencia frente a unas determinadas formas del comportamiento humano reflejadas en un texto de ficción. Así, el castigo divino por incumplimiento de una promesa es algo que se enmarca perfectamente en las creencias cristianas de los narradores y así lo expresa especialmente la narra- 
dora de la segunda versión. En general, en las versiones analizadas, las ideas moralizantes - sean explícitas o subyacentes- se pueden esquematizar de la siguiente forma, similar a un ciclo bremondiano (Bremond 1970): estado de carencia $\longrightarrow$ proceso de mejoramiento $\longrightarrow$ transgresión de una norma $\longrightarrow$ sanción $\longrightarrow$ nuevo estado de carencia $\longrightarrow$ nuevo proceso de mejoramiento $\longrightarrow$ transgresión de una norma $\longrightarrow$ sanción $\longrightarrow$ proceso de mejoramiento $\rightarrow$ fortalecimiento de una norma $\longrightarrow$ restablecimiento del orden quebrantado.

\section{INTERPRETACIÓN GLOBAL}

10.1. Se confirma en las dos versiones del cuento analizado el planteamiento de Regina Valdés (1987), según el cual este tipo de literatura da una visión unitaria del hombre y de su capacidad de transformación. De hecho, en ambas versiones el joven-toro sólo es toro a partir de ciertas horas del día, y su bravura y crueldad animal dejan de ser tales cuando pierde el encantamiento en el que se halla. En ambos textos las transformaciones físicas del héroe tienen incidencia directa en la metamorfosis espiritual/moral en un sentido positivo. O sea, el cambio se da para mejor.

10.2. Ese cambio para mejor que experimenta el héroe, conduce a otra significativa característica del cuento tradicional, al menos del analizado en estas páginas. Se trata de un clima general positivo para salir de situaciones dolorosas o angustiosas. En ambas versiones prima la confianza en que si se llevan a cabo tales o cuales acciones y se respetan tales o cuales requisitos, se volverá al estado de normalidad o se alcanzará el bien deseado. En estas dos versiones, dada la escasa presencia del elemento maravilloso - descontados el encantamiento y otras pocas acciones mágicas-, el logro de los objetivos es el resultado del esfuerzo puramente humano. Los obstáculos están para ser derribados. Tal pareciera ser el espíritu del cuento, el que, en último término, viene a constituir la didáctica final, esa enseñanza global implícita que está por debajo de la moral explícita ya indicada.

10.3. Otro aspecto que se deriva de la lectura de estas narraciones es un decidido sentido machista, a través del cual la mujer aparece estando al servicio del hombre. Así, madres y jóvenes mujeres se desviven por satisfacer las exigencias del joven-toro. Él exige a la madre que le traiga mujeres para casarse con alguna de ellas. Si no le sirven, las destruye. Luego, a la elegida, por haberse atrevido a mirarlo mediante el fósforo o 
la vela, le impone una penitencia; mientras él, tranquilamente espera, lejos, que ella, arrastrando sus zapatos de hierro, lo encuentre. El machismo se reafirma con el matrimonio final, ya que para ella el premio es él.

10.4. Una nueva dimensión del optimismo que impera en las versiones de este cuento es el que proviene de la confianza en los frutos de la solidaridad social. Esencialmente en ellas las comunicaciones humanas son programáticas, porque están destinadas a pedir favores, principalmente a aquéllos que no podrían negarse. Así, tanto la comadre como la vecina, no sólo ofrecen consejos e información; también facilitan a sus hijas en calidad de préstamo para objetivos que no les son explicados. Tal confianza en la ayuda que se recibirá, lleva a la madre del joven a decir: "Voy a ir a pedir la otra ahija(d)a a la comadre. La comadre tiene que aguantar todavía. Para eso es mi comadre. Obviamente, aquí estamos frente a un latente supuesto social de origen cristiano, que ha alcanzado una fuerte aplicación en los sectores populares de Chile, el comadrazgo o el compadrazgo, gracias al cual las personas no sólo se ayudan para enfrentar la soledad, sino también pueden llevar adelante proyectos prácticos.

10.5. Una significativa diferencia ofrecen las dos versiones en relación con lo que aquí hemos reconocido como la moral explícita de cada una. En la primera versión, probablemente por carecer de elementos propios del ámbito de la religión, la moraleja es no sólo inesperada, también es tardía. Esto es, en los últimos enunciados dice el narrador: "Así que por eso dicen que el que la sigue, la consigue. Y si la pilla, se la lleva, pu(es)n. Esto en referencia al logro de la tercera hija, quien encuentra finalmente al joven y se casa con él. Por el contrario, la moraleja de la segunda versión es integral en tanto está presente desde el principio hasta el fin. Se trata de una moral religiosa que castiga el incumplimiento en que incurre la madre que no podía tener un hijo, la cual, al tenerlo más tarde, se olvidó de la promesa que había hecho al Señor. Su castigo fue doble porque, primero, su hijo se transformó en toro y, después, cuando éste recobró la normalidad y contrajo matrimonio, no vino a ver a su madre "porque no pagó la promesan. Es altamente probable que la clara moral de esta versión sea producto de la fuerte orientación religiosa protestante que nos evidenciaron la narradora y su familia cuando nos entregaron esta versión. En efecto, la narradora accedió a relatar su versión del cuento sólo después de haber obtenido el parecer del pastor de su iglesia evangélica.

10.6. Finalmente, llama la atención el hecho de que ambas versiones del cuento se diferencien por el modo en que se enfrentan las interacciones 
personales cuando éstas son socialmente desniveladas. En la primera versión, hay varias manifestaciones de resentimiento social por parte del narrador cuando se refiere a encuentros con esas características. Concretamente, utiliza los nombres "el futre" y "la rica", dos formas que en Chile tienen una clara connotación despectiva para referirse respectivamente al hombre y a la mujer que poseen mayor poder económico. En la segunda versión no hay nada de esto, probablemente porque la religiosidad señalada mediatiza la rivalidad social presente en la primera.

\section{LAS DOS VERSIONES}

\subsection{El torito encantado}

Narrador: Roque Orellana Salgado

Edad: 71 años

Escolaridad: No tiene

Actividad: Labores agrícolas

Localidad: Nació en Traiguén, pero reside en Quino desde los 6 años de edad.

Fuente: Aprendió varios cuentos de boca de narradores adultos en 1958, cuando estuvo enfermo en el Hospital de Traiguén.

Fecha de registro: 12 / $06 / 98$.

Siempre la gente campesina tenía sus chistes ${ }^{2}$ y tenía su familia, porque así es la tabla de la ley de Dios: que tiene que salir la familia. Y había una señora y tenía un joven $\mathrm{pu}(\mathrm{es})^{3}$. Había otra vecina que tenía tres niñas. Entonces el joven este se encantó. Porque antes habían cosas de encanto, nombraban encanto. Entonces este joven era un encanto que había. El hijo de la señora esa era un encanto. Entonces estaba convertido en un toro. Dicen que cuando llegaba él, en la noche, llegaba a la casa, llegaba guapiando ${ }^{4}$ pu(es), bramaba el toro. Y llegaba a su casa y se iba a su pieza. Y ahí en la pieza entonces después se desarmaba: quedaba la sonajera de huesos; se desarmaba y se convertía en el joven pu(es) ¿ah?; se convertía, porque él era un encanto no más pu(es), en un toro. Y en el día, en la mañana, antes que aclarara se

2 chiste: en el sentido de 'dificultad, obstáculo' (5a. ac. DRAE-I: 650). La sigla DRAE corresponde a REAL ACADEMIA ESPAÑOLA, Diccionario de la lengua española (Madrid: Espasa Calpe, vigésima primera edición, 2 vols., 1992).

3 pu(es): forma reducida de pues. Se representa poniendo la terminación entre paréntesis. En general, esta forma cumple sólo una función reforzativa.

4 guapear: 'echar bravatas' (DHACH: 120). Es común la forma guapiar, con pronunciación antihiática. La sigla DHACH corresponde a ACADEMIA CHILENA DE LA LENGUA, Diccionario del habla chilena (Santiago de Chile: Universitaria, 1978). 
convertía en toro y se iba a una laguna que había pu(es). Así que llegaba y se tiraba a la laguna: no lo veía nadie en la laguna. Entonces un día, un día cualquiera, le dijo a la mamá:

-Mamá - le dijo-, necesito de matrimoniarme 5 . Y necesito que me vayas a pedir la hija a la vecina, pronto, para matrimoniarme. Pero sí tiene que ser valiente, porque tú sabes cómo llego yo a la casa y cómo me voy. Así que tú tienes que advirtil.le ${ }^{6}$, hacel.le saber. Y si alguna se anima a casarse conmigo, yo me caso con ella. Pero el casamiento se hace después que yo me desencante; porque ahora estoy encantado; no puedo. Pero quiero tenerla en la casa.

Así que la mamá sirvió de... al otro día de ir a(d)onde ${ }^{7}$ la vecina pu(es). Y fue y le conversó. $\mathrm{Y}$ estuvieron tomando mate y tortilla y un pedazo de queso y qué sé yo, ahí en el campo. Antes no fallaba eso. Entonces le pidió a la hija y le dio todas las recomendaciones. Y llamaron a las chiquillas. Y estaban las tres niñas ahí y le(s) dijeron pu(es), le(s) hicieron ver.

$\mathrm{Y}$ una dijo:

- Bueno, yo me caso - dijo-. Eso que no lo conozca, que no lo vea, eso no me importa. Me voy pa(ra) allá; y me voy con usted; y qué sé yo.

Así que una se interesó y se fue a la casa. Así que en la noche, cuando llegó el torito, llegó, venía guapiando el torito. ¡Puta!, a la chiquilla le tiritaban los vestiditos, porque antes no eran na(d)a vestiditos pu(es); eran vestidazos ${ }^{8}$ : llegaban a los tobillos, abajo. Entonces le tiritaban los vestidos a la niña, porque venía un toro guapiando y le habían dicho que ése era el joven pu(es). Pero sí que no tenía que miral.lo ni por nada al joven, en la noche.

Entonces (es)taba la niña en su pieza. Llegó el toro. ¡Por la...!, cuando se desarma el toro al la(d)o, abajo, al la(d)o de la cama, se desarma y queda la sonajera de huesos. Y se pone a gritos la chiquilla pu(es). Y no tenía que gritar nada. Ella tenía que estar ahí no más; esperar que llegara el joven; porque tenía que convertirse y tenía que estar ahí. La niña no resistió pu(es). Sintió la sonajera de huesos.

-No —dijo-, esto no es pa(ra) mí —dijo-.

¡Y pega los gritos! ${ }^{9} \mathrm{Y}$ él se convierte en toro otra vez y la pesca a corna(d)as. La mató pu(es), la liquidó el toro. Porque ésa era la sentencia. Si había alguna cosa que dé luz o de algo que... entonces él la mataba, la liquidaba. Así que la mató pu(es). Al otro día corrió la nombrada ${ }^{10}$ : la niña, un velorio, la hija.

5 matrimoniarse: 'unirse en matrimonio, casarse'. El DRAE consigna matrimoniar como verbo intransitivo, pero confirma que en Chile se usa como pronominal (DRAEII: 1338).

6 Es común la lateralización de vibrante simple cuando va seguida de lateral: r.l. $>$ l.l.

7 El debilitamiento de algunas consonantes, especialmente - $d$ - (intervocálica) y $s$ (implosiva), en casos extremos, se señala entre paréntesis.

8 El narrador establece claramente la diferencia semántica entre la forma diminutiva marcada con el sufijo -ito y la forma aumentativa (en otros casos ponderativa) marcada con el sufijo -azo (cfr. Oroz 1966: 286).

9 pegar gritos: 'dar gritos, gritar'.

10 correr la nombrada: 'difundirse una noticia'. 
Pasó un mes del velorio, del sepulto ${ }^{11}$; pasó un mes, un poco más sería, ya empezó el torito:

-Mamá, necesito que me busques una niña; necesito una niña.

Así que las más cerca que habían y las mejores niñas que habían en esos barrios, eran de allá, de la señora aquella que tenía las tres hijas. Pero ya le quedaban dos pu(es); porque a una ya el toro la había liquida(d)o. Se fue allá otra vez. Y allá le conversó otra vez y ahi una dijo:

- Ya - dijo-, iyo voy! — dijo-. ¡Y cómo no lo va a resistir uno que se desarme el otro al la(d)o! -dijo- ¡Yo voy! —dijo-.

Así que ella fue pu(es). (Es)taba en la pieza del joven, cuando llegó el toro guapiando y escarbando; y pescaba las tablas, las hacía pe(d)azos por arriba. El catre lo andaba tra(y)endo por allá y por acá. No resistió tampoco: pegó los gritos. En seguida no más que la mató. Se fue pu(es) al agua el toro. (Es)tuvo una semana el toro que no salía del agua. Hasta que pasó el velorio, pasó todo, ahí salió el toro; vino a la casa otra vez.

-Mamá - le dijo-, te he dicho que le recomiendes, que le recomiendes... ¡Hasta cuándo voy a matar niñas! Yo no quiero matar niñas. Yo quiero tener una compañera, una niña que me comprienda ${ }^{12}$ y que me entienda y que me acompañe. $Y$ tener en la casa a esa niña. Pero que no se ponga a gritos a hablar aquí cuando esté yo.

$\mathrm{Ya}$.

- Hijo - le decía la mamá-, ¿pero a quién te voy a buscar?

—No, vaya allá no más — le dijo-, a(d)onde la señora. ¿Cómo no va a salir una hija valiente, que no la tenga que matar? ¡No puede ser! ¡Tiene que haber una valiente!

Así que a los pocos días después la señora, la mamá, fue otra vez a(d)onde la mámá de la otra niña, con pena, a contal.le de su chiste y que el torito le dijo: "Mamá, me vas a buscar una novia, porque si no, tú la vas a pasar mal también". Así que la mamá, como tenía ya su recomendación de que necesitaba el torito una compañera en la casa, fue, por todo y por todo fue a(d)onde la señora y le dijo allá. Entonces la última niña que quedaba en la casa dijo:

-Bueno - dijo-, yo voy y lo espero; y cuando él llegue, ahí veo pu(es). Que sea lo que Dios quiera - dijo- ¿ah? Pa(ra) esperal.lo a él, me resisto; no me resisto -dijo- ¡qué sé yo!

Así que se fue pu(es). En la tarde fue a la casa; estaba en la pieza; pero no tenían que tener luz: todo oscuro. Cuando venía el torito, venía lejos el torito, guapiando, guapiando.

- Por ahí viene - dijo- el torito, guapito ${ }^{13}$, pero ¿cómo va a ser tanto — dijoque no $\operatorname{los}^{14}$ vamos a entender?

Entonces llegó el torito; se fue a su pieza; pasó; llegó a la casa; anduvo guapiando por el la(d)o de ajuera de la casa; rodiando la casa; le pegaba unas corna(d)as en la esquina; la hacía crujir la casita.

11 sepulto: 'inhumación, funerales'.

12 comprienda: forma diptongada de comprenda, por similitud con formas que regularmente llevan diptongo, como entienda, defienda, etc.

13 guapito: forma diminutiva de guapo, que no tiene aquí el sentido hispánico de 'bien parecido', sino el muy chileno de 'bravucón, estricto' (cfr. Oroz 1966: 412).

14 En las formas pronominales, es frecuente la asimilación de nos a los (cfr. Oroz 1966: 297). 
- iCaramba! - dijo la niña-, tiene fuerza este carajo; pero yo voy a quedar calla(d)ita no más — dijo-; no le voy a decir ni una cosa. Que haga lo que quiera él.

Se quedó ahí la niña. Entró pa(ra) a(d)entro el torito; llegó a la pieza, escarbando por aquí y por allá. Igual también sacaba los pedazos de tablas pa(ra) arriba y... guapiando. La niña, na(d)a pu(es), amocha(d)ita ${ }^{15}$ por el rinconcito (d)e la cama no más. Entonces llegó el torito; se desarmó al la(d)o (d)el catre. La niña lo que tenía que hacer cuando llegara el joven, se desarmara y se fuera al la(d)o del... a sentarse al catre, la niña tenía que levantar la tapa. Era todo lo que tenía que hacer: levantal.le la tapa. Y ahi se acuestaba ${ }^{16}$ el joven y se tapaba. Así que resistió ésa pu(es), resistió esa niña. Llegó el toro guapo; y llegó y llegó a la pieza y se acostó en la pieza con la niña. La niña resistió pu(es). Al otro día se levantó el toro; se armó y se fue. Ella no lo vio, no lo conoció. Y estaba recomendada de que no tenía que miral.lo, por nada. Él si la rochaba ${ }^{17}$ que ella lo estaba mirando, el mal era de ella, iba a ser mal para ella.

Y ya (es)taba por desencantarse el torito de su laguna, ya estaba pa(ra) venirse a la casa, para ser el joven de la casa pu(es). Estaba por encanto no más por unos años. Entonces la niña (siempre uno quiere conocer, quiere ver, siempre como... no sé... cualquier persona tiene interés de vel.lo bien y, si uno lo ve, ojalá tomal.le la mano $\mathrm{pa}(\mathrm{ra}) \ldots \mathrm{pa}(\mathrm{ra})$ vel.lo mejor), entonces la niña le dijo a una vecina que tenía en otro la(d)o:

-Vecina -le dijo-, hace una semana que estoy casa(d)a con el torito de la laguna y no lo conozco.

- ¿Y tú lo querís ${ }^{18}$ conocer, hija - le dijo la viejita.

- Sí pu(es) - le dijo-, lo quisiera conocer pu(es).

- Bueno, yo te voy a dar el consejo - le dijo ella-, pero no vas a salir pilla(d)a sí pu(es), porque yo - le dijo- te doy el consejo, pero tenís que obedecer tú; si no, el mal va a ser tuyo y mío. Cuando llegue el joven - le dijo-, el torito, y esté en la casa y llegue y se acueste, y tú te quedás dispierta ${ }^{19}$ un rato; y entonces - le dijotenís una caja de fósforos adebajo ${ }^{20}$ de la cabecera - le dijo- y después con un fosforito no más, pa(ra) que no te suene la caja de fósforos, con un fosforito, cuando notís que él esté durmiendo, entonces prendís el fósforo - le dijo-, lo mirás y apagás al tiro ${ }^{21}$ el fuego. Que no te vaya a pillar él.

15 amochadita: forma diminutiva de amochada 'encogida como se tratara de un mocho, es decir, de un trozo corto de madera para aserrar' (cfr. mocho en DHACH: 144).

16 acuestaba: Nótese la extensión de las formas diptongadas del verbo acostar a una forma regularmente sin diptongo: acostaba.

17 rochar: en Chile 'sorprender a alguien en algo ilícito' (DRAE-II: 1804; cfr. DHACH: 201).

18 Las formas verbales voceantes, como querís, tenís, notís, prendís, quedás, mirás, apagás, etc. aparecen con mayor frecuencia en el habla de los personajes.

19 Como se sabe, las formas con disimilación vocálica del tipo despierta $>$ dispierta no son extrañas al habla popular. En este mismo texto aparece la forma dispertaron por despertaron.

20 adebajo: forma protética de debajo.

21 al tiro: locución adverbial equivalente a 'al momento, en seguida'. En Chile, es uso de todos los niveles sociales (Oroz 1966: 350). 
Ya, la otra pa(ra) conocer (a) su esposo, dejó el fósforo, dejó la caja ahí en la noche. Estaba durmiendo el joven, cuando ella pesca el fósforo y lo prende y lo alumbra pu(es). Y era tan simpático ${ }^{22}$ el joven que la niña se quedó mirándolo. No apagó na(d)a el fósforo al tiro. Se queda mirándolo, con el fósforo ahí. Y en eso se dispierta el joven; se dispierta. Y como lo había alumbra(d)o la niña, no se pudo convertir en su encanto.

Entonces le dijo:

- Yo me retiro. Vai(s) a gastar - le dijo- siete pares de zapatos de fierro, y en un jardín de flores me vas a encontrar.

Se fue pu(es); no se armó el torito. Se fue el joven; se desencantó a(d)onde lo alumbraron pu(es). Y ya estaba por desencantarse; si le quedaba unos días no má(s) pu(es), una semana. Entonces se fue el joven. $Y$ en esa semana que el joven había esta(d)o con la niña, le había traído el toro un espejo, una peineta y una manzana, a su esposa pu(es). Entonces, cuando él se desencantó, eso quedó ahí pu(es).

Entonces ella dijo:

-Se fue; lo perdí - dijo.

Lo quería y le gustó tanto el joven. Entonces se mandó hacer los siete pares de zapatos de fierro.

- iY lo voy a buscar! - dijo-, jlo voy a buscar!

Se hizo los pares de zapatos de fierro y salió en busca de su joven. Anduvo, anduvo, anduvo; gastó un par de zapatos de fierro; se puso otro por ahí; y siguió pegando ${ }^{23}$. Anduvo por varias partes: no lo podía encontrar. Pasó por la madre del Sure, del viento Sure; y en la noche le pasó a pedir alojamiento a la abuelita ahí. alojar.

-Abuelita, ¿me das alojamiento? Ando andando - le dijo- y no tengo (d)onde

-Pero, hija - le dijo la abuelita-, yo tengo un hijo muy mañoso ${ }^{24}$ y no admite a nadien aquí en la casa. No te puedo dar alojamiento.

-Pero, abuelita - le dijo-, yo soy valiente - le dijo- y me gano ${ }^{25}$ por ahí, en cualquier rincón que me deje alojar.

-Bueno - le dijo la abuelita.

Así que la dejó que alojara: alojó donde la madre del Sur. Se ganó a(d)entro de un cajón grande que tenían; ahí se ganó la niña. Y cuando llegó el viento Sure:

-Mamá - le decía el viento-, mamá, hay olor extraño aquí —le decía.

-No, hijo - le decía la mamá-, tranquilo, calma(d)o no más, hijo -le decía-, no pasa na(d)a.

Así que se calmó el viento Sur. Así que alojó ahí. Al otro día se fue la niña. El viento partió otra vez al otro día, el viento Sur, se fue. Así que la niña tomó desayuno y se fue. Anduvo, anduvo, anduvo, después anduvo harto y llegó a(d)onde otra abuelita, era la mamá del viento Norte. Y ahí venía, le pidió alojamiento. Y le dijo la viejita:

-Pero, hija, yo tengo un hijo, el viento Norte - le dijo-; y es mañoso: da vuelta cuanto pilla - le dijo.

22 simpático: En el español de Chile, a menudo equivale a 'apuesto, de hermosas facciones'.

23 seguir pegando: 'seguir andando'.

24 mañoso: 'de costumbres irregulares e inadecuadas para la convivencia' (cfr. DHACH: 141).

25 ganarse: forma común para indicar la acción de 'situarse, ubicarse'. 
- Yo soy valiente - le dijo ella-. Yo creo que resisto, aunque me dé vuelta. Me echa a(d)entro de un cajón -le dijo- Yo creo que aunque me dé vuelta - dijoyo no voy a gritar. Ahí me quedo.

-Ya pu(es), hija - le dijo la viejita.

Así que le dio alojamiento pu(es). A eso como a la medianoche venía el viento Norte; zumbando venía; y unos remolinos que venían...; crujía la casa a(d)onde el viento la empujaba: ¡Fuiiiich!

Llegó el viento:

-Mamá -le dijo-, hay carne humana aquí.

-No, hijo, no hay na(d)a.

-No, sí hay un olor - le dijo- a carne humana. ¿Dónde está? ¿Dónde está?

-No, hijo, calma(d)o, si no pasa nada. Y tranquilo, tranquilo no más, Norte.

Ya, se calmó el viento pu(es); a su mamá le hizo juicio ${ }^{26}$, se calmó.

Así que la niña estaba a(d)entro de un cajón grande; allá a(d)entro estaba esperando si acaso el viento le iba a dar vuelta el cajón; pero no: le habló la mamá no más, así que el viento se tranquilizó. Así que ahí alojó la niña. Al otro día, igual caso, se fue el viento Norte. Y ya a ella le dieron desayuno: tomó desayuno y se fue. $\mathrm{Y}$ ahi le quedaba un par de zapatos no más ya; se le habían gastado los otros seis; le quedaba un par de zapatos de fierro. Pero ella llevaba su espejo, su peineta, su manzana, que nadie se las veía; ella llevaba sus cosas guardadas. Entonces se fue. Cuando ya se le iba rompiendo el último par de zapatos de fierro, la suela ya... ya iba pisando con el cuerito, se encuentra con un palacio. Entonces dijo:

-Allí hay un palacio. Voy a pedir trabajo. Ya no me quedan zapatos pa(ra) andar - dijo.

-Sí -le dijeron-, se necesita una niña aquí.

Le dieron trabajo en el palacio. Y le entregaron la pieza de la niña arriba, segundo piso. Entonces la niña ya recibió su pieza y fue; una vez que ya le entregaron su pieza, sacó sus cosas, las colgó, las ordenó; pescó la manzana, la puso en la ventana; y justo estaba como ser esa ventanita, claro que ésa no tiene manzana; pero así, $\mathrm{pa}(\mathrm{ra})$ ese la(d)o, entonces, en la mañana, cuando alumbró el sol, brilló la manzana en la ventana del chalé, del palacio, allá. Y la joven ve un palacio que había al frente y ahí estaba el caballero, en el otro palacio; ahí se había casa(d)o; ahí estaba viviendo. Entonces, en la mañana, cuando la niña se fue a hacer aseo y después fue a la ventana, sacó su espejo, sacó su peineta y se empezó a peinar, en la ventana. Entonces la manzana estaba a diario ahí pu(es). Pero ella en la mañana sacó su espejo y peineta y se peinó. Así que la rica que había al frente ya era casa(d)a, porque estaba casa(d)a con el marido de ella; la rica estaba ahí; y la codicia...: la quedó mirando:

- iChuta! ${ }^{27}$, aquélla tiene cosas de oro allí —dijo-. ¿Quién será que ha llegado?

Entonces fue; mandó al mozo:

- Mira - le dijo-, vas a ir allí, al palacio; vas a hablar con... con [alguien de] ahí y vas a preguntar quién llegó último y quién vive en esa pieza que está acá. Así

26 bacer juicio a uno: locución verbal que significa 'obedecer, acatar las recomendaciones de alguien' (cfr. DHACH: 128).

27 ¡chuta!: exclamación eufemística por ¡chucha!, voz grosera que hace referencia a los órganos genitales externos de la mujer. 
que fue el mozo y preguntó y le dijeron que era una niña que había llega(d)o hacían unos pocos días no más. Entonces fue el mozo; volvió a la casa; le dijo:

-Patrona, una niña que llegó y (es)tá trabajando ahí.

Entonces la patrona, codiciosa, le dijo:

-Anda, trata de hablar con ella y dile acaso no me vende la manzana que tiene en la ventana.

Ya pu(es), el mozo fue; habló con la niña y le dijo que la patrona de allá le quería comprar la manzana que tenía en la ventana; si acaso no se la vendía.

Entonces la niña le dijo:

- Mira - le dijo-, yo la manzana no se la vendo; se la puedo regalar. Solamente -le dijo- que le dé permiso a su marido [para] que venga a alojar conmigo una noche. Si viene su marido a alojar conmigo una noche - le dijo-, la manzana es de ella al otro día.

Así que el mozo volvió pa(ra) allá y le dijo:

- Patrona, esto y esto me dijo. Y la manzana se ve bonita, sí señora.

Y la patrona, la rica codiciosa, quería tener la manzana.

-Ya pu(es) -dijo.

Entonces la codiciosa le dijo al mozo que fuera y le dijera a la niña que sí, que le daba permiso [a su marido] pa(ra) que fuera a alojar una noche con ella. Pero que no se fuera a arrepentir de entregal.le la manzana al otro día.

- Ni por nada - le dijo la niña- El hecho es que venga.

Entonces la señora le dio la cena en la noche y le preparó una agüita caliente (como casi siempre toma uno una agüita caliente después de comer, una tacita de cualquier hierbecita) y le preparó y le dio una gotita de (a)dormidera ${ }^{28}$ al esposo. Así que el esposo fue a alojar al otro palacio, allá, con la niña, al segundo piso pu(es).

Y la patrona de allá le dijo al mozo:

-Tú vas a ir también con tu patrón - le dijo- y vas a alojar en la pieza de al la(d)o - le dijo-. Pero no te vas a dormir -le dijo-. Tenís que escuchar qué es lo que va a pasar -le dijo.

Así que el mozo, bien recomenda(d)o pu(es). Ya pu(es). Tenía que irse sin dormir esa noche.

El mozo dijo:

— ¡Cuánto más una noche sin dormir!

Entonces fue; el esposo se acostó con la niña; llegó la hora que se fueron a acostar a la pieza. Y el mozo en la otra pieza de al la(d)o. Y en cuanto se acostó el caballero no más, se quedó dormido pu(es); se quedó roncando.

Y (en)tonces el mozo lo escuchaba:

-Ronca mi patrón —decía- ¿Quién es el que ronca? ¿Será mi patrón?

Y ahi ${ }^{29}$ la niña le empezó a hablar: la historia de ellos; de cuando él estaba encantado; de cuando se había desencantado; y que la culpa había sido de ella, por alumbral.lo. Le contó toda la historia la niña. Y el patrón durmiendo; no escuchaba nada pu(es).

28 La voz adormidera pierde su $a$-inicial tal vez porque se asocia directamente con el verbo dormir.

29 El adverbio de lugar abi muchas veces se pronuncia con antihiato: $a b i$. Además, semánticamente, suele asumir un sentido temporal equivalente a 'en ese momento'. 
Al otro día llegó el día, dispertaron y el hombre se vistió y se fue. Y la manzana, el mozo:

-Aquí está la manzana.

El mozo le llevó la manzana pu(es), de oro.

- Bueno - dijo la rica-, ya tengo la manzana.

La niña no tenía ya la manzana ahí, pero en las mañana salía con su espejo y su peineta y se peinaba ahí pu(es). Entonces, a los pocos días, la rica codiciosa le dijo:

- ¿Acaso no me vendes una de las otras prendas?: la peineta.

Allá vino el mozo otra vez. La misma respuesta, la niña:

- Si le da permiso a su marido pa(ra) que venga a alojar conmigo, le regalo la peineta.

Así que el mozo era el correo: pa(ra) allá, pa(ra) acá.

Ya la otra aceptó, pu(es), que:

-Bueno, yo le doy permiso a mi marido que vaya a alojar.

Pero la esposa sabía, porque le tenía la trampa de que le daba la (a)dormidera; entonces no pasaba na(d)a pu(es); se quedaba dormido no más pu(es). Entonces el mozo llegó allá con la misma respuesta.

Y el mozo escuchaba. Entonces el mozo le dijo al patrón:

-Patrón - le dijo-, el otro día, cuando fuimos a alojar al frente, la niña le habló toda la noche -le dijo- Y le dijo esto y esto y esto - le decía y le explicaba-. Y usted no escuchaba na(d)a, patrón.

-No -le dijo él.

-Esta noche trate de no dormir pu(es), patrón, y escúchele. Eran cosas tristes que estaba hablando la niña.

-Ya -le dijo.

Así que comió en la tarde ya; todo combina(d)o, ya listo; comió; le prepararon la agüita; se la tomó; a dormir allá al frente, se fue allá a dormir otra vez. El mozo, a escuchar.

Entonces la niña le volvía a repetir y le volvía a decir y ahi le hablaba de las hermanas después y le contaba la historia. Entonces, el mozo escuchando. Al otro día se llevó la peineta. Así que ya tenía dos prendas allá.

Otro día, después de una semana sería, volvió otra vez la rica codiciosa a que no le vendía el espejo. $\mathrm{Y}$ ahi la niña le dio la misma respuesta:

-Que venga su marido, que quiero hablar con él.

Así que vino; le dio la respuesta.

El mozo le dijo:

-Patrón, yo le voy a salvar la campana ${ }^{30}$ - le dijo-, porque no es posible le dijo- que todo lo que le dice la niña allá — le dijo- usted no lo escuche. Póngase - le dijo- en la noche, cuando la patrona le dé la agüita de té, póngase un guatero $^{31}$-le dijo- adebajo de la camisa, por ahí, entonces a menos si la patrona

30 salvar la campana a alguien: 'salir de una situación difícil por algún medio inesperado'. Esta locución verbal parece provenir del boxeo, deporte en el que se utiliza el toque de campana para indicar el término de cada una de las partes o tiempos de que consta un combate.

31 guatero: 'bolsa de goma para colocar agua caliente y aplicarla en alguna parte del cuerpo' (cfr. DHACH: 121). Esta voz se ha formado mediante el lexema inglés water ('agua') + el sufijo castellano -ero. 
se descuida, usted se vacea ${ }^{32}$ el agua en el guatero - le dijo- y no se la tome. $\mathrm{Pa}(\mathrm{ra})$ que pueda escuchar, patrón, lo que la niña le está diciendo pu(es).

Entonces, bueno, el futre ${ }^{33}$ ya pu(es) así lo hizo: se puso un guatero en el pecho. Pero a menos se descuidó la señora, le trajo la agüita, fue última y ya... demoró un poco el caballero:

-Que se enfríe un poco - dijo.

A menos que se salió la señora un poco pa(ra) allá y se echó el agua; no se la tomó. Después llegó la hora ya: fuera pa(ra) el frente. Así que ahí fue a alojar el caballero con la niña, al frente, atra vez. Ahi la niña le empezó a decir esto y esto y esto y esto y esto. Ahí el caballero la escuchó pu(es), porque estaba despierto pu(es); no se había tomado la (a)dormidera. Entonces estaba despierto. Ahí él escuchó y entonces le dijo el caballero:

- Ya - le dijo- hiciste el sacrificio de buscarme, así que yo -le dijo-ahora tu sacrificio que hiciste te lo recompenso: yo me vengo contigo -le dijo.

Así que se volvió el rico del frente con la empleada que había en el otro chalé, en el otro palacio; se volvió el hombre. Entonces, al volverse pa(ra) acá, dijo:

-Ese espejo, esa peineta y esa manzana no le pertenecen a ella, porque yo no había escucha(d)o nada; yo no sabía. Así que ignorantemente, in fragantemente ${ }^{34}$ ella no le puede quitar ni la manzana, ni la peineta, ni el espejo. Así que esa manzana tiene que volver acá. Así que el caballero se vino; dejó la señora casada por las leyes allá; y le trajo la manzana y le trajo la peineta y le trajo el espejo a la niña que había cumplido con buscal.lo. Así que por eso dicen que "el que la sigue la consigue.. Y si la pilla, se la lleva pu(es).

Así que quedaron ahí, nuevamente con su manzana, su peineta y su espejito. $\mathrm{Y}$ deben estar viviendo todavía pu(es), felices y contentos.

\subsection{El joven que se convertía en toro}

Narradora: Mercedes Caro Riquelme

Edad: 82 años

Escolaridad: $2 .^{\circ}$ año básico

Actividad: labores del campo y del hogar

Localidad: Villa Coihueco (comuna de Galvarino)

Fuente: Escuchó este cuento de boca de su padre y también de boca de una tía, cuando era pequeña.

Fecha de registro: 10/07/98.

32 vacea: variante fónica de vacía. En general, el verbo vaciar suele presentar varias formas vacilantes en el español de Chile (Oroz 1966: 335-337).

33 futre: 'hombre rico y bien vestido'; 'patrón' (cfr. DHACH: 114).

34 in fragantemente: forma de etimología popular (asociación con la voz fragante) para explicar la locución adverbial en flagrante 'de manera repentina' (< del latín in flagranti). 
Éste era un rey que se casó con una joven; eran reyes jóvenes. Entonces ellos querían tener niños. $\mathrm{Y}$ hacía muchos años que ellos eran casados y no podían tener ni un niño. Entonces la reina le contó a una vecina y le preguntó que cómo podría hacerlo para tener un niño, que ella su amor era tan grande para tener un niño; porque ellos eran tan solos y tenían tantos bienes y cómo iban a dejar sus bienes después al morir si no tenían un hijo, no tenían nada.

Entonces le dijo la vecina:

- Mire, hágale una promesa al Señor de que usted tenga un niño, pero usted le ofrece lo que pueda dal.le.

Entonces la señora lo halló muy bueno y le hizo la promesa al Señor: de pagar la promesa si ella tenía un niño. Entonces el Señor le concedió de que tuviera un niño.

Ya estaba grandecito el niño, ya un joven muy hermoso; la señora muy feliz, muy contenta; pero de la promesa de Dios se olvidó; nunca se acordó. Cuando un día el joven se volvió un toro. Y va ella y le conversa a la vecina que por qué sería que su hijo se había convertido en un animal. Entonces le dice ella:

- Vecina, ¿y usted se recuerda que hizo una promesa al Señor o no?

-No - le dijo.

Quizás no quiso pagal.la, quizás qué promesa le hizo, no quiso pagal.la. Entonces el joven, que ya era un joven de unos veinticinco años, empezó a clamal.le que él necesitaba una compañera. Llegaba él a su pieza, tenía su pieza; nadie dentraba ${ }^{35}$ a su pieza, solamente la mamá a hacel.le su cama no más. Y él ahí se despojaba del cuero de vacuno que tenía y se acostaba: un verdadero príncipe. Pero él al presentarse afuera tenía que venir con su capa que tenía puesta de un animalito.

-iQué! —dijo ella—, yo no he hecho promesa, yo no he hecho nada - pensó ella, entre ella.

Y él insistía: que quería mujer, que quería mujer. Entonces dijo ella, astuta la reina:

- Voy a ir a(d)onde mi comadre. Ella tiene tres hijas. Que me pase una hija dijo- pa(ra) mi hijo.

Y fue a(d)onde la comadre, pero con astucia. Llegó allá y le dijo a la comadre:

-Vengo a vel.la, comadre - le dijo-, vengo a pedil.le un favor.

- ¿Qué favor sería, comadre? -le dijo.

- Que le diera permiso a mi ahija(d)a - le dijo- para que fuera a acompañarme unos días.

-Estas chiquillas no salen nunca, comadre - le dijo-, no tienen costumbre.

-Pero como no es tan lejos, comadre - le dijo-; es cerca. ¿Y cómo, si es mi ahija(d)a -le dijo-, cómo no le va a dar permiso?

-En fin -le dijo-, le voy a dar permiso, pero por un par de días no más.

Ya. Se vino con la niña y cuando llegó la tarde, ella no le contó a la niña lo que pasaba, na(d)a; sino que le dijo, cuando ya llegó la hora de dormir:

-Mira, aquí hay una cama - le dijo-, ahí vas a dormir.

La niña se sacó su ropa, se desvistió y se acostó. Quedó dormida. Cuando llega él y la pilla en su cama. Y la pesca y la saca. La descuartizó. La mató, oiga. No ve que éste llegaba convertido en un animal. Entonces él cuando la vio, y la niña no le

35 dentraba: del verbo dentrar, variante antigua de entrar (Oroz 1966: 343 y 348). 
habló ninguna cosa, él la sacó, la tiró lejos. Y al otro día, cuando se fue él, viene la mamá al cuarto y va a ver a la niña: ¡toda hecha pedazos!

$Y$ dijo ella:

— ¿Qué pasó, Señor? ¡Ay! ¿Qué va a decir mi comadre?

Y llegó en la noche, la sacó y limpió la pieza. Y llegó la noche y llegó otra vez el hijo. Él se metió a un encanto por causa de que la mamá no pagó nunca la promesa. De día se iba muy lejos a su encanto; y volvía de noche.

Entonces, cuando llegó en la noche, se acostó él y empezó a proferir: que quería mujer, que quería mujer.

- Mañana voy a ir - dijo- a(d)onde la comadre, que me pase la otra chiquilla, mi otra ahija(d)a. ¿Cómo a tanto - dijo- no se va a enamorar de alguna y va a dejar de estar pidiendo? - dijo-. Él no puede salir a buscar mujer. ¿Quién lo puede pescar ${ }^{36}$ así? - dijo- . Nadie le puede tener cariño, si él es un verdadero animal —dijo.

Entonces fue a(d)onde la comadre otra vez y le dijo que la niña estaba muy bien allá; estaba aprendiendo a leer; que le diera permiso a la otra, pa(ra) que estuviera un par de días con la otra; y la otra la iría a dejar.

Ya la mamá, pensativa:

-Pero, comadre -le dijo-, ¿no me estará haciendo traición?

-No, comadre - le dijo, ¿cómo se le ocurre?

Le llevaba regalitos: una cosita y otra; y entonces le dijo:

- Bueno, pero más de tres o cuatro días no.

Ya, entonces cuando llegó a la casa, ya llegó la hora de dormir, se fue...

-Aquí tenís ${ }^{37}$, hija - le dijo-, cama pa(ra) que te acostís; pero lávate antes que te acostís - le dijo.

La niña fue y se acostó, carga(d)a de sueño, maltrata(d)a; se acostó y se quedó dormi(d)a. Cuando llegó él, juh! empieza... la saca de la cama, la desarmó tam(b)ién. Mas que cuando la vio bota(d)a al otro día la mamá, la niña ya la sacó.

- iAy, Señor! —dijo-, ya llevo dos, dos hijas menos — dijo- y este hombre que no agarra camino ${ }^{38}$. ¡Por Dios, Señor! — dijo- ¿Qué voy a hacer ahora? —dijo-. ¿Qué cuenta le voy a dar a la comadre? Pero voy a ir a buscar (a) la otra - dijo- Voy a ir a pedir la otra ahija(d)a a la comadre. La comadre tiene que aguantar todavía. Para eso es mi comadre. Yo no puedo salir por ahí a buscar gente, mas este hombre no es un hombre -dijo- que una niña lo pueda enamorar: él es enfermo - dijo.

Y fue a(d)onde la comadre otra vez a buscar la otra: que después estarían las tres juntas; que las otras estaban muy contentas y aprendiendo a leer...

Pero ésa no fue na(d)a aturdida. Entonces ella le dijo:

-Ya llegó la hora de dormir. Aquí está la cama pa(ra) que duermas. Si quieres lavarte, aquí hay jabón; aquí hay de todo -le dijo.

Y ésa se lavó bien, se bañó, se pintó, bien pinta(d)a, se empolvó, se peinó y se acostó.

Cuando llegó el animalito, sintió ella que abrieron la puerta. Ella se sentó en la cama y lo vio que dentró. Y, cuando lo vio que dentró, fue ella y lo abrazó al joven. Y el joven botó su capa que tenía y la abrazó a la niña y la besó. Y le dijo:

36 pescar: 'tomar en cuenta, considerar'.

37 Este texto, como el anterior, contiene varias formas verbales voseantes en el habla de los personajes.

38 agarrar camino: 'encontrar solución a un problema'. 
-Tú habís sido la única que has respondido a mi amor.

Después, al otro día, cuando se levantó la mamá y los vino a ver, entonces a ella la encontró, pero al hijo no. Entonces el hijo ya se puso... se ponía la cuestión esa pa(ra) salir no más. Y volvía en la tarde, en la noche.

A la casa llegaron mujeres curiosas y una de ellas le preguntó:

- ¿Y cómo era?

—iLindo! -le dijo-. ¡Es lindo!

- ¿Y los ojos cómo los tiene? -le dijo.

- Los ojos los tiene, parece, verdosos.

-Oye - le dijo- otra: mira, yo te voy a pasar este pedacito de vela.

-Sí -le dijo.

-Priéndelo ${ }^{39}$ tú - le dijo- cuando esté durmiendo y lo mirás bien. Entonces la niña le hizo juicio a la mujer. ¡Y no le cayó un cerote de vela en la cara a él!

Le dijo el joven:

- Mira - le dijo-, no tienes la culpa tú; pero por un lado sí - le dijo-, porque le obedeciste a esa mujer que te habló. Ahora - le dijo- yo me voy a ir, te voy a dejar le dijo-, aunque fuiste el único amor que yo tuve y que yo quise, como tú me quisiste a mí - le dijo-. Ahora yo me voy; no me vas a ver. Si tú sos una mujer fiel a mí —le dijo-, para que llegues a(d)onde mí, mira - le dijo-, tenís que mandar a hacer siete pares de zapatos de fierro; porque siete años vas a tener que caminar - le dijo- al fundo de los... al Palacio de los Siete Garfios - le dijo-. Allá me voy yo. Yo me vuelvo una paloma ahora y me voy; no vuelvo más. Y si tú llegas allá antes que yo me case -le dijo-, aunque yo esté de novio, me caso contigo. Y si no - le dijo-, te quedarás sola para toda tu vida.

La niña lloró desespera(d)a. Y le dijo a la suegra lo que había pasa(d)o.

- ¡Ay! - le dijo-, ¿y pa(ra) qué fuiste a hacer eso?

- Por curiosidad no más.

Ya la suegra le mandó a hacer los siete pares de zapatos de fierro. Y siguió caminando la niña; caminó mucho. Ya tenía que llegar a un río muy grande, muy ancho, un río que era lo que se llamaba un río. Y pa(ra) pasar el río era lo bueno ahí pu(es). De repente, ella estaba senta(d)a a la orilla del río, llorando: que ¿cómo iba a pasar el río?, cuando era un río tan hondo, tan profundo y ancho. Y llega un águila y le dice:

- ¿Y por qué lloras, Marita?

- Porque quiero pasar pa(ra) el otro la(d)o del río -le dijo-, y no puedo pasar.

- iAh! - le dijo-, mira, dame siete corderos a mí y yo te paso.

- ¿Y cómo me vas a pasar? - le dijo ella.

- ¡Bah!, montás en acha ${ }^{40}$ en mí - le dijo- y yo te paso.

- ¿Entonces?

- iMira!, en aquellas piedras, ahí hay una ruma de piedras, ahí hay corderitos -le dijo-. Tomas siete corderitos de esos - le dijo- y en seguida yo te paso.

39 La forma priéndelo (con diptongo) en vez de préndelo revela influencia de los verbos irregulares, que tienen formas diptongadas y no diptongadas.

40 en acha: o al acha es locución adverbial equivalente a 'a la espalda' (cfr. DHACH: 36). 
Ella fue. Tomó siete lauchoncitos ${ }^{41}$; los mató y los echó en una bolsa y los trajo.

- Ya -le dijo-, aquí me vas a dar uno en la partida. Y después que ande mucho $\mathrm{pa}$ (ra) allá, cuando ya me dé hambre, yo te voy a pedir otro.

Ya, entonces, en ese acuerdo, él se comió el lauchón; y en seguida la niña subió en el cogote de él, y tomadita de las alas. Y siguió volando el aguilucho. Y siguieron caminando, caminando. Ya habían anda(d)o mucho; pero todavía no llegaban ni a la mitad del río, cuando él dijo:

$\rightarrow$ iHambre!

Ya ella le pasó otro lauchoncito. Y seguía él volando y se lo iba comiendo. Y caminaron, caminaron. Ya llegó a la mitad.

Ya un poco más pa(ra) allá, le dijo que tenía hambre otra vez. Le dio otro lauchoncito. Entonces, cuando ya se comió ése, ya tupidito ${ }^{42}$ le da hambre de nuevo. Pero todavía le falta mucho pa(ra) pasar.

Entonces ella le dijo:

-Pero me quedan dos no más; ya no me quedan más. Vas a tener que caminar más -le dijo-, porque ¿qué te voy a dar después?

Ya siguió caminando, bastante que había camina(d)o, cuando le dijo:

- ¡Hambre!

Le pasó el otro.

-Ya me queda uno - dijo.

Y miró. Todavía le faltaba mucho que caminar. Cuando le dice el otro, después que había camina(d)o:

- ¡Hambre!

- ¡Ay, Señor! — dijo ella—, se terminó todo. Y todavía falta tanto.

Ya siguieron caminando, mucho más adelante, cuando él le dice:

-iHambre!

- No tengo nada - le dice.

- Bueno, si no me das nada, te planto aquí en el río. Éste es como un mar le dijo-, así que te vas aguas abajo. No vas a poder salir.

Entonces dijo ella:

- ¡Señor!, ¿qué le voy a dar?

-Dame - le dijo- la carne de tu pierna.

- ¿Y cómo voy a andar yo después? -le dijo.

-Yo no sé pu(es).

Entonces ya, que ya la tiraba e(d)entro del agua; le hacía mojarse los pies.

- Ya - le dijo ella-, come mi pierna.

Se comió toda la carne de la pantorrilla.

$\mathrm{Y}$ siguieron caminando. $\mathrm{Y}$ todavía nada pu(es), todavía faltaba tanto, cuando otra vez le dice:

- iHambre!

- ¿Y qué voy a hacer ahora? -le dijo-. ¿Te voy a dar la otra pierna?

${ }^{41}$ lauchoncito: es voz derivada de laucha, nombre de origen mapuche para la 'rata' (DHACH: 131). Nótese el uso del sufijo aumentativo -ón y del diminutivo -ito en una misma palabra

42 tupidito: forma diminutiva de tupido. En este contexto aparece con función adverbial equivalente a 'de modo muy frecuente'. 
-Sí -le dijo él.

Y le siguió comiendo la carne de la pierna. Y siguió caminando, caminando. Ya le faltaba poco. Ya la iba a llevar muy afuera; ya le faltaba muy poco; pero le dijo:

-Y ahora dame qué comer, porque me falta.

- ¿Y qué te voy a dar ahora?

-Dame tu cara - le dijo.

Y le puso la cara la niña.

- ¿Y qué va a ser de mí cuando salga afuera ${ }^{43}$ ?... Bueno, afuera voy a morir —dijo- y no me van a ver; no voy a seguir más; ya me voy a terminar.

Ya siguió caminando hasta que salió afuera. Y cuando salió afuera la niña, sus piernas estaban igual como eran antes; su cara estaba más linda que lo que era antes.

Y le dijo:

- Hasta aquí... hasta aquí te acompaño - le dijo-. Y ahora camina tú -le dijo.

Ya llevaba como dos pares de zapatos. Y siguió caminando, caminando, andar y andar, andar por los caminos. Preguntaba por el fundo.

— ¡Uh! - le decían—, todavía le falta más de tres o cuatro años para llegar allá. Eso es muy lejos.

- ¿Y cómo usted busca ese fundo? - le dijo una señora-. Ese palacio es de un rey -le dijo-, (d)onde habita toda la joventu(d) ${ }^{44}$-le dijo- que está encanta(d)a. Entonces le dijo un caballero:

- Yo la llevo. Vamos, caminemos.

Y la llevó el caballero en un coche. Y la fue a dejar muy lejos pa(ra) a(d)entro. $\mathrm{Y}$ le dijo:

- Hasta aquí. Aquí - le dijo- hay una casita. Converse con esos ancianos y a lo mejor los ancianos por ahí pueden saber algo; porque siempre entre los ancianos se escuchan muchas cosas -le dijo.

Y entonces cuando llegó a la casita de los ancianos, ahí conversó con los ancianos. Le preguntaron pa(ra) a(d)ónde iba. Ella dijo pa(ra) a(d)onde iba. Y le dijeron que entonces (es)tuviera ahí unos días. $\mathrm{Y}$ entonces ellos se iban a anoticiar, porque ellos tenían gente mucha pa(ra) a(d)entro que podían saber algo.

Ya ella estuvo un tiempo ahí, conversando con los ancianos. Salían a andar en el día; volvían en la tarde. Cuando de repente se juntó con una señora: que iba haber un casamiento, pero muy elegante, muy lindo. Se casaba un joven con una reina. Y a ese casamiento iban a llegar invitados de todas partes, de todos lugares. Pero, cuando salió a andar, oyó decir que ese palacio estaba muy lejos.

$\mathrm{Y}$ entonces ya la señora le dijo:

-Vamos a ir ahí, hay gente que recorre mucho más pa(ra) allá, andando.

- Ya - dijo ella - estos zapatos ya no me sirven.

Botó los zapatos.

- Me queda un parcito de zapatos y ya no me está quedando más -dijo-. Bueno, puede ser que alcance o no alcance - dijo- a llegar allá.

Ya llegaron a una casa. La señora le encargó:

-Vengo a dejal.le - dijo- una niña que busca el Palacio de los Siete Garfios, (d)onde están los príncipes encanta(d)os -le dijo.

43 salir afuera: es forma redundante frecuente en el español popular de Chile

44 joventud: variante fónica de juventud; seguramente presenta o porque como forma derivada se la relaciona directamente con la voz joven. 
- ¡Ah! - le dijo la señora - sí, va haber un casamiento y van a invitar de una parte y otra, va haber una reunión muy grande - le dijo- Nosotros querimos ${ }^{45}$ ir tam(b)ién. Bueno, vamos a ver si podimos ir.

Ya conversando, conversando, salían ellas a pasiar ${ }^{46}$ por las casas, a ver si encontraban más noticias. Más allá encontraron a una señora que ya se estaba preparando para ir a esa gran boda. Porque esa boda iba a ser muy linda, iba a ser un banquete muy grande, iban a invitar a mucha gente.

Y con esa noticia, dijo la niña:

-Aquí está bueno. Aquí sí que estamos ya a la puerta.

Y dijo la señora:

- ¿Y usted, señorita, de dónde viene?

— Uh! — dijo la niña-, yo vengo de muy lejos. Y fíjese que pa(ra) poder llegar a estas partes, pa(ra) acá, ya llevo seis pares de zapatos gasta(d)os. Me queda este solo par de zapatos. Y yo para llegar a esa parte a(d)onde voy -le dijo-, si no alcanzo con éste, no alcanzo a llegar, ya no va a ser mi felicidad - le dijo-; ya voy a morir por aquí y no voy a alcanzar lo que yo deseaba, lo que yo perdí.

- ¿Y qué perdió usted? - le dijo una niña joven.

- ¿Sabe lo que yo perdí, señorita? - le dijo-. Yo perdí mi amor. Por una mujer que se fue a meter - le dijo- a conversar conmigo. Y yo le hice juicio: perdí mi amor -le dijo.

- ¿Y eso anda buscando? ¿Y de tan lejos?

- Sí -le dijo-. Él me dijo que lo buscara.

- Ya - le dijo- ¿Y cómo se llama el joven?

-No sé -le dijo-, porque yo no alcancé a conversar con él mucho. No sé cómo se llama - le dijo.

Así que entonces:

- Ya -le dijo-, entonces usted váyase preparando pu(es). Y quédese aquí; y en seguida váyase con nosotros pu(es); nosotros vamos a ir.

Entonces ella preguntó:

- ¿Hay alguna tienda por aquí?

- Sí -le dijeron.

Entonces ella fue; se compró zapatos; se compró traje; se compró un pañuelo; y se compró unas letras de oro. En seguida las letras de oro las puso al pañuelo.

Entonces cuando trajeron la torta para los novios; la pusieron encima de una mesita. Entonces ella vio que dejaron la torta y dijo:

- ¿La torta de los novios?

- Sí - le dijo una-, es para los novios.

Y ella le dijo:

- ¿Me podría consentir que dejara un pañuelito ahí?

—Cómo no pu(es)! ¿Por qué no?, en la mesa — le dijo.

Ya. Fue y dejó así el pañuelito al lado de la torta. Y el pañuelo tenía el nombre de ella, de la niña.

Entonces, cuando vino el novio con la novia, vinieron a ver la torta. Y él ve el pañuelo y mira las letras: se entristeció.

45 querimos: La terminación -emos, propia de los verbos en -er, se asimila frecuentemente a la terminación -imos, propia de los verbos en -ir (cfr. Oroz 1966: 307).

46 pasiar: variante fónica antihiática de pasear. 
Y le dijo ella:

- ¿Y por qué te entristeces? ¿No te quieres casar conmigo? ¿Qué pasó?

-No -le dijo-, no puedo.

- ¿Y por qué no puedes? -le dijo-. ¿Se arrepintió?

- Sí -le dijo.

- ¿Y por qué?

-Ésta es mi novia -le dijo-, la que está en este pañuelo. - Bueno - le dijo ella-, ¿qué le vamos a hacer?

Y ella estaba por allá, fondia(d)ita ${ }^{47}$. Y él la miraba, miraba; para un la(d)o miraba; para otro: ¿a(d)ónde la veía?; no la podía ver. Y de repente se paró ella y la vio él. Y él fue y se abrazó de ella y le dijo a todo el público:

—iÉsta es mi novia! No me puedo casar con otra - le dijo-. Ésta es mi mujer. Por ella voy a ser feliz. Porque yo no era un hombre: yo era un verdadero animal. ¿Por qué? Por causa de mis padres - dijo.

- ¿Y qué hicieron tus padres? -le preguntaron.

- Porque mis padres..., yo no sé si fue promesa, qué fue lo que hicieron, mi rey -le dijo (porque el rey le preguntaba)—. Y a lo mejor hicieron una promesa y no la pagaron. Y yo me convertí en un animal. Esta niña me desencantó -le dijo- Y a ella le debo la vida. Y por eso yo le dije que yo me venía a este palacio - dijodel fundo de los Garfios. A ese castillo yo me venía y en ese castillo iba a vivir. Y si ella alcanzaba a llegar aquí, yo me casaba con ella, aunque estuviera de novio. Y ahora no le puedo faltar - dijo.

Así que todos le dieron el visto bueno: de que estaba bien pu(es). Y se casó con la niña. Pero ésta tuvo que gastar los siete pares de zapatos de fierro. Eso es lo que gastó.

Y siguió la fiesta grande, una gran fiesta, pu(es) oiga. ¡Qué! hubieron ${ }^{48}$ fiestas por todos los cerros: las bodas de los reyes. Y quedaron viviendo por allá. Ni vinieron a ver a la mamá; porque no pagó la promesa.

\section{BIBLIOGRAFÍA CITADA}

BRemond, Claude. 1970. "Morphology of the French Folktale". Semiótica II, 3: 247-276. Camarena, Julio. 1995. "El cuento popular". Anthropos, Revista de documentación científica de la cultura 166-167: 30-33.

- y MAXIme Chevalier. 1995. Catálogo tipológico del cuento folklórico español. Madrid: Gredos.

Dannemann, Manuel. 1998. Enciclopedia del folclore chileno. Santiago de Chile: Universitaria, cap. VII "El cuento": 131-151.

DijK, Teun A. VAN. 1992. La ciencia del texto. Barcelona: Paidós. 2." reimpresión.

${ }^{47}$ fondiadita: 'escondida'. En el español de Chile se usa el verbo fondear con el sentidio de 'aislar, esconder' (cfr. DHACH: 113).

48 Aun cuando el verbo haber cuando expresa 'existencia de' tenga carácter impersonal y la regla exija las formas de singular, es evidente la tendencia popular a usar las formas de plural. 
LIDA, MARÍA ROSA. 1976. "El cuento popular hispanoamericano y la literatura", en $E l$ cuento popular y otros ensayos: 69-72. Buenos Aires: Losada.

Oroz, Rodolfo. 1966. La lengua castellana en Chile. Santiago de Chile: Universitaria. Pino SaAvedra, Yolando. 1960. Cuentos folklóricos de Chile. Santiago de Chile: Universitaria.

- 1970. Cuentos orales chileno-argentinos. Santiago de Chile: Universitaria.

- 1992. Nuevos cuentos folklóricos chilenos de raíces hispánicas. Santiago de Chile: Universitaria.

PINON, ROGER. 1965. El cuento folklórico (como tema de estudio). Buenos Aires: EUDEBA. Pisanty, Valentina. 1995. Cómo se lee un cuento popular. Barcelona: Paidós. Propp, Vladimir. 1981a. Morfología del cuento. Madrid: Fundamentos. 5." ed. - 1981b. Las raices bistóricas del cuento. Madrid: Fundamentos. 3." ed. THOMPSON, STITH. 1972. El cuento folklórico. Caracas: Universidad Central de Venezuela. VAldÉs B., Regina. 1987. "La imagen del Hombre en el cuento". Aisthesis 20: 23-26. 